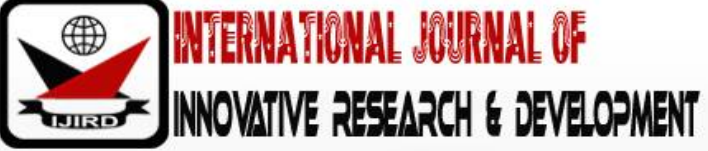

ISSN 2278 - 0211 (Online)

\section{Factors Affecting Productivity of Seaweed Farming (Eucheuma Cottonii) in South Konawe Regency, Indonesia}

\begin{tabular}{|c|}
\hline Ine Fausayana \\
Lecturer, Department of Agribusiness, Halu Oleo University, Kendari, Indonesia \\
Yusriadin \\
Lecturer, Department of Agribusiness, Halu Oleo University, Kendari, Indonesia \\
Budiyanto \\
Lecturer, Department of Agribusiness, Halu Oleo University, Kendari, Indonesia \\
Rosmawaty \\
Yecturer, Department of Agricultural Extention, Halu Oleo University, Kendari, Indonesia \\
Yani Taufik \\
Lecturer, Department of Agricultural Extention, Halu Oleo University, Kendari, Indonesia
\end{tabular}

\begin{abstract}
:
The research aims to know the affecting factors of productivity of seaweed farming in South Konawe Regency. The population of this research is all of seaweed farmers in South Konawe Regency which account for 498 farmers; the number of samples is 221 farmers. Samples were selected by Cluster Random Sampling method which then chosen randomly by means of Simple Random Sampling method. Type and data source used is primary and secondary data. The data was technically collected by direct interview with respondents and study literature. This research was conducted in July 2018 - November 2018. The variable comprises construction of area, labour, number of seeds, ropes stretch, and farming experience. The data analysis is the production function of Cobb-Douglas. The result of this research simultaneously (F-test) shows that the width of construction of area, number of labour, number of seeds, stretch ropes and farming experience significantly influence the productivity of seaweed farming. It is similar to T-test which partially reveals that the farming productivity is influenced by the width of construction area and stretch ropes. However, the number of labours, number of seeds, and farming experience are not influencing seaweed farming productivity in South Konawe Regency.
\end{abstract}

Keywords: Productivity, farming, seaweed

\section{Introduction}

Seaweed is one of Indonesia leading commodities in revitalizing fisheries through the Minapolitan program. This is because it is supported by Indonesia potential as an archipelago with 13,667 islands (Yusuf, S et al, 2018) and has a seaweed cultivation area of 1.1 million ha or $9 \%$ of the total area of potential aquaculture which is 12,123,383 ha and the utilization rate is around 25\% (KKP, 2015) with the potential for dry seaweed production to average 16 tons per ha. Based on these data, if all land is utilized for the development of seaweed farming, the production of dried seaweed is expected to reach 17,600,000 tons per year at a price of Rp 4.5 million per ton (DKP, 2008). Seeing this potential shows that seaweed farming is one type of aquaculture that has important economic values and opportunities to be developed.

This condition is supported by an increase in demand for seaweed in the domestic and foreign markets. The results of the study by Anggadiredja et al (2006) estimate that the world market for seaweed processed products increases by around $10 \%$ per year for semirefine carrageenan (SRC), jelly and alginate for industry.

Southeast Sulawesi is one of the provinces that is able to contribute to the increase of Indonesian seaweed exports as well as meeting the needs and demands of foreign countries and has competitiveness and excellence even though the results of Tradable Resource Cost Ratio (TRCR) are less able to compete with East Lombok Regency (Luhur et al, 2012). In addition to the ecological factors and technology used by farmers, the factor of low capital owned is also very influential (Fausayana, I et al 2017). This is also supported by the results of the research of Hasibuan and Bedy (2008) stating that the low competitiveness of seaweed is caused by external factors and domestic factors.

South Konawe Regency is one of the seaweed production centers in Southeast Sulawesi Province. Data from the Central Statistics Agency in 2014 and 2015 showed that the production of seaweed in South Konawe Regency was 105,072 tons and 100,710 tons. The decline in the production and productivity of seaweed in South Konawe Regency is 4,362 tons. The basic problem is in terms of traditional cultivation techniques. The handling of seaweed cultivation in South Konawe Regency by farmers is based on hereditary experiences and habits. To increase the productivity and income of seaweed farmers, several studies have been carried out, including Ine Fausayana (2018) making integration of inverted mosquito 
net seaweed cultivation with fish cages. Research from Buschmann, H, A, et al (2017), that there are several important aspects to increasing the value of seaweed biomass, namely maintaining ecosystems by reducing coastal nutrient loads. Productivity measurement can be done by means of Total Factor Productivity (Ondrej and Jiri, 2012).

According to Teniwut, TA (2018), low education factors can also cause a decline in seaweed production. because low education can hinder ability in innovation. Prihaningrum, et al (2001) stated that in seaweed cultivation techniques, spacing of seeds is one of the technical factors that influence the growth of seaweed due to its relationship with nutrient absorption. Based on these conditions, it is interesting to do research on the factors that influence the productivity of seaweed farming in the South Konawe Regency.

\section{Research Methods}

This research was conducted in South Konawe Regency. The location of the study was determined purposively with the consideration that South Konawe Regency is one of the centers of seaweed production in Southeast Sulawesi Province. This research was conducted in July 2018 - November 2018.

The population in this study were all seaweed farmers in South Konawe Regency which numbered 498 (Population from 6 villages namely Tinanggea Village, Bungin Permai, Akuni and Torokeku Village in Tinanggea Sub District. Watumeeto and Pamandati Village in Lainea Sub District). Determination of the study sample was conducted using the Cluster Random Sampling method then the study sample was chosen randomly using the Simple Random Sampling method. Determination of the number of samples using Slovin formula (Umar, 2004) to obtain a total sample of 221 people.

The types and sources of data in the study consisted of primary data and secondary data. Data collection techniques used were direct interviews with respondents and literature studies. Variables in the study included construction area, labor, numberof seeds, numberof stretches, and farming experience. The data analysis used is: CobbDouglas production function :

$\mathrm{Y}=\mathrm{aX}_{1}{ }^{\beta 1} \mathrm{X}_{2}{ }^{\beta 2} \mathrm{X}_{3} \beta 3 \mathrm{X}_{4}^{\beta 4} \mathrm{X}_{5}^{\beta 5} \mathrm{e}^{\mathrm{u}}$

where:

$\mathrm{Y}=$ Productivity $(\mathrm{IDR} / \mathrm{Kg})$

$\mathrm{X} 1=$ Construction of area (ha)

$\mathrm{X} 2$ =Labor (HOK)

$\mathrm{X} 3=$ Number of Seeds (IDR)

$\mathrm{X} 4=$ Number of stretches rope $(\mathrm{Kg})$

$\mathrm{X} 5=$ Farming experience (Year)

$\mathrm{e}=$ confounding variable

\author{
$\mathrm{a}=$ Constants \\ $\beta 1=$ Regression coefficient, factor $\mathrm{X} 1$ \\ $\beta 2=$ Regression coefficient, factor X2 \\ $\beta 3=$ Regression coefficient, factor X3 \\ $\beta 4=$ Regression coefficient, factor X4 \\ $\beta 5=$ Regression coefficient, factor X5 \\ $\alpha=0.05$ or error rate of $5 \%$
}

\section{Result and Discussion}

\subsection{Inputs of Seaweed Farming}

There are several inputs used in seaweed farming activities in South Konawe Regency, including: stretch rope, anchor rope, main rope, seeds tying, net, tarpaulin, ball buoys, bottle buoys, boats, seeds, fuel oil, machinery and labor. More clearly about the use of seaweed farming inputs can be seen in Table 1.

\begin{tabular}{|c|c|c|c|c|c|}
\hline No. & Inputs & Highest & Lowest & Average & Productivity \\
\hline 1. & Stretch Rope $(\mathrm{Kg})$ & 500 & 25 & 110 & 16 \\
\hline 2. & Anchor Rope (Kg) & 24 & 4,8 & 6,1 & 287,61 \\
\hline 3. & Main Rope (Kg) & 45 & 9 & 11 & 152,93 \\
\hline 4. & Tying Rope of Seeds (Ball) & 200 & 10 & 43,72 & 40 \\
\hline 5. & Net (Meter) & 450 & 20 & 99,94 & 18 \\
\hline 6. & Tarpaulin (Unit) & 5 & 1 & 1,2 & 1.381 \\
\hline 7. & Ball Buoys (Unit) & 20 & 4 & 5 & 345 \\
\hline 8. & Bottle Buoys (Unit) & 5.000 & 250 & 1.098 & 1,6 \\
\hline 9. & Boats (Unit) & 1 & 1 & 1 & 1.756 \\
\hline 10. & Seeds (Kg) & 10.000 & 500 & 2.195 & 0,8 \\
\hline 11. & Fuel Oil (Liter) & 52 & 5 & 7,8 & 224 \\
\hline 12. & Machinery (Unit) & 1 & 1 & 1 & 1.756 \\
\hline \multicolumn{7}{|r|}{ Table 1: Use of Inputs in Seaweed Farming Activities in South Konawe Regency in 2018 } \\
\hline
\end{tabular}

Table 1 shows that the inputs used in seaweed farming activities in South Konawe Regency consist of 12 inputs with the largest use are seeds, which are an average of 2,195 $\mathrm{kg}$ while the inputs with the smallest use are boats and engines, but both of these inputs have a fairly high price compared to other inputs.

\subsection{Use of Labor Inputs}

In seaweed farming activities in South Konawe Regency, there are three main activities that require the use of labor, among others: tying seeds, cleaning ropes and harvesting. More details can be seen in Table 2. 


\begin{tabular}{|c|c|c|c|c|}
\hline No. & Activities & Highest & Lowest & Average \\
\hline 1. & Tying Seeds (HOK) $*$ & 92 & 6 & 27 \\
\hline 2. & Cleaning the Rope (HOK) & 18 & 0,57 & 5 \\
\hline 3. & Harvesting (HOK) & 48 & 4 & 15 \\
\hline
\end{tabular}

Table 2: Use of Labor Inputs in Seaweed Farming Activities in South Konawe Regency in 2018

* HOK: Working Day

Table 2 shows that of the three activities in seaweed farming, the activity of tying the seedlings requires a greater number of labor outflow than the other two activities, namely cleaning the rope and harvesting. As many as $27 \mathrm{HOK}$, the average outflow of labor needed in seaweed farming, while cleaning the rope requires an average of 5 HOK of labor and harvesting $15 \mathrm{HOK}$. The number of workers in seaweed farming activities is obtained from the calculation of the number of working people, the number of working days and the number of hours worked then divided by 1 working day for men and women.

\subsection{Factors Affecting Productivity of Seaweed Farming}

Several independent variables used in this study such as construction area, labor, seedlings, stretches rope, and farming experience as variables to be analyzed using multiple non linear regression analysis to see which variables influence and how much influence on the productivity of seaweed farming in South Konawe Regency.

\subsection{Coefficient of Determination (R2)}

The results showed that the coefficient of determination (R2) was 0.86 , which means that $86 \%$ of the diversity of the dependent variable is productivity can be explained by the diversity of independent variables, namely construction area, number of labor, number of strands, stretching experience and farming experience, while the remaining $14 \%$ is explained by the diversity of other variables not included in the regression model. The coefficient of determination (R2) of 0.86 indicates that the regression equation model in good research is used to explain the relationship between the dependent variable (Y) and the independent variable (X) because the value of R2 approaches 1.

\subsection{Simultaneous Test (F Test)}

The F test is used to determine whether the overall variable area of construction, labor, number of seeds, number of stretches, and experience of farming together influence the dependent variable (productivity).

The results showed that a significance value of 0.00 was smaller than $\alpha(0.05)$. It means that the independent variables (construction area, labor, number of seeds, number of stretches, and farming experience) used in the regression model together influence the dependent variable (productivity) of seaweed farming.

\subsection{Partial Test (t Test)}

Partial test ( $t$ test) is used to determine the effect of independent variables (construction area, labor, number of seeds, number of stretches ropes and farming experience) individually or individually on the dependent variable (productivity) of seaweed farming, assuming that the independent variable others are constant. More details can be seen in Table 3.

\begin{tabular}{|c|c|c|c|c|c|c|}
\hline \multicolumn{7}{|c|}{ Coefficients $^{a}$} \\
\hline \multirow{2}{*}{\multicolumn{2}{|c|}{ Model }} & \multicolumn{2}{|c|}{$\begin{array}{l}\text { Unstandardized } \\
\text { Coefficients }\end{array}$} & \multirow{2}{*}{$\begin{array}{c}\begin{array}{c}\text { Standardized } \\
\text { Coefficients }\end{array} \\
\text { Beta }\end{array}$} & \multirow[t]{2}{*}{$\mathbf{t}$} & \multirow[t]{2}{*}{ Sig. } \\
\hline & & B & Std. Error & & & \\
\hline \multirow[t]{6}{*}{1} & (Constant) & 5.223 & .119 & & 43.894 & .000 \\
\hline & Construction of Area & -.707 & .044 & -.500 & -16.095 & .000 \\
\hline & Labor & .008 & .022 & .012 & .339 & .735 \\
\hline & Number of Seeds & .017 & .024 & .030 & .705 & .482 \\
\hline & Number of Stretch Rope & .712 & .029 & 1.055 & 24.226 & .000 \\
\hline & Farming Experience & .030 & 017 & .047 & 1.762 & .079 \\
\hline
\end{tabular}

Table 3: Partial Test Results (Test T) SPSS Version 16.0 Program

Table 3 shows that the results of the analysis with the SPSS Version 16.0 program, see whether the independent variables (construction area, labor, number of seeds, stretch of rope, and farming experience) influence and how much influence they have on the dependent variable (productivity). Cobb-Douglas production function equation as follows:

$\mathrm{Y}=\mathrm{a} \mathrm{X}_{1}{ }^{\beta 1} \mathrm{X}_{2}{ }^{\beta 2} \mathrm{X}_{3}{ }^{\beta 3} \mathrm{X}_{4}{ }^{\beta 4} \mathrm{X}_{5}{ }^{\beta 5} \mathrm{e}^{\mathrm{u}}$

$\mathrm{Y}=5,223 \cdot \mathrm{X}_{1}-0,707 \cdot \mathrm{X}_{2}{ }^{0,008} \cdot \mathrm{X}_{3}{ }^{0,017} \cdot \mathrm{X}_{4}{ }^{0,712} \cdot \mathrm{X}_{5}{ }^{0,030} \cdot \mathrm{e}^{\mathrm{u}}$

The completion of the Cobb-Douglas production function is always logged and changed its physical form into a linear function, the following equation is obtained:

$\operatorname{Ln} Y=\operatorname{Ln} a+\beta_{1} \operatorname{Ln} X_{1}+\beta_{2} \operatorname{Ln} X_{2}+\beta_{3} \operatorname{Ln} X_{3}+\beta_{4} \operatorname{Ln} X_{4}+\beta_{5} \operatorname{Ln} X_{5}+\operatorname{Ln} e$

$\operatorname{Ln} Y=\operatorname{Ln} 5,223-0,707 \operatorname{Ln} X_{1}+0,008 \operatorname{Ln} X_{2}+0,017 \operatorname{Ln} X_{3}+0,712 \operatorname{Ln} X_{4}+\quad 0,030 \operatorname{Ln} X_{5}+\operatorname{Ln} e$

Then it is converted into an anti-linear form using the exponential formula on Microsoft Excel, so that the following equation is obtained: 
$\mathrm{Y}=185,489 \cdot \mathrm{X}_{1}^{-0,707} \cdot \mathrm{X}_{2}{ }^{0,008} \cdot \mathrm{X}_{3}{ }^{0,017} \cdot \mathrm{X}_{4} 0,712 \cdot \mathrm{X}_{5}^{0,030} \cdot \mathrm{e}^{\mathrm{u}}$

Based on the results of the analysis, the discussion of the effect of each independent variable on the dependent variable (productivity) of seaweed farming in South Konawe Regency is explained in the following sections:

\section{Construction of Area}

The results of the regression analysis indicate that the significance value of the area construction variable is 0.00 less than $\alpha$ (0.05). This means that extensive use of construction has a significant effect on the productivity of seaweed farming. The regression coefficient on the area construction variable of -0.707 shows that 1 unit increase in the area construction of seaweed farming in South Konawe Regency will reduce the productivity value of -0.707 . This means that seaweed farming will experience a decrease in productivity if the area construction is added, this is because seaweed farmers in South Konawe Regency generally have an average area construction that is sufficient for farming, which is 1.3 Ha with an average of 220 stretches of rope. This condition is proven by the number of constructions of 1 unit (100m x $50 \mathrm{~m}$ ) which can only accommodate as many as 200 stretches of rope. So that the productivity of seaweed farming will decrease if the farmers make area construction additions without adding to the number of stretches.

\subsection{Labor}

The results of the regression analysis indicate that the significance value of the labor variable is 0.735 greater than $\alpha$ (0.05) with a coefficient of 0.008 . This means that the use of labor does not affect the productivity of seaweed farming in South Konawe Regency. This is because activities in seaweed farming that use labor only bind the seeds, clean the rope and harvest. The use of the largest number of labours both in number and value is in the activity of binding seaw eed seeds on average as many as 27 HOK with an average wage of IDR 19,000 compared to two other activities, namely cleaning the rope and harvesting. This means that in general seaweed farming activities can be carried out by family workers without involving outside workers who need wages. Based on the coefficient value of 0.008 , it shows that every 1 HOK of labor for seaweed farming activities only produces $0.008 \mathrm{~kg}$ of dried seaweed production. This means that the use of the number of outpouring of labor for seaweed farming activities is far greater than the results obtained.

\subsection{Number of Seed}

The results of the regression analysis indicate that the significance value of the variable number of seeds is 0.482 greater than $\alpha$ (0.05). This means that the use of seeds does not affect the productivity of seaweed farming. This is because the average use of seeds in seaweed farming activities is obtained from the production itself. The number of uses of seaweed seeds is obtained from the multiplication of the number of seeds per stretch with the number of stretches. The average use of seaweed seeds is $2,195 \mathrm{~kg}$. If seen based on the regression coefficient value of 0.017 , it indicates that every $1 \mathrm{~kg}$ of seaweed seedlings used only produce $0.017 \mathrm{~kg}$ of dried seaweed production. This means that the use of seaweed seedlings is far greater than the yield obtained so that in general the use of seeds does not affect the productivity of seaweed farming.

\subsection{Number of Ropes}

The results of the regression analysis show that the significance value of the variable number of stretches is 0.00 less than $\alpha(0.05)$. This means that the use of a stretch of rope significantly influences the productivity of seaweed farming. While the regression coefficient on the variable number of ropes stretches of 0.712 shows that each addition of the number of stretches rope of seaweed in South Konawe Regency by $1 \mathrm{~kg}$ will increase the productivity value of $0.712 \mathrm{~kg}$. This can be seen the average stretch rope usage is $110 \mathrm{~kg}$ at a price of IDR $4 / \mathrm{kg}$. While based on the processed results the primary data shows a stretch rope productivity value of 16 . This means that every $1 \mathrm{~kg}$ of stretch rope can produce $16 \mathrm{~kg}$ of dried seaweed production. The size of rope usage in seaweed farming activities in South Konawe Regency is influenced by the number of constructions owned by farmers.

\subsection{Farming Experience}

The results of the regression analysis indicate that the significance value of the variable experience of farming is 0.079 greater than $\alpha(0.05)$. This means that the experience of farming does not significantly influence the productivity of seaweed farming. This can be seen from the coefficient value of 0.030 indicating that the increase in experience of farming for 1 year only produces $0.030 \mathrm{~kg}$ of dried seaweed production. This means that the length of seaweed farming is not comparable to the yield obtained. This means that generally seaweed farming activities in South Konawe Regency can be done by young farmers who are already in productive age. This is supported by Fausayana et al. (2017) who stated that farmers who are more experienced in seaweed farming activities are very reluctant to take risks. Conversely, farmers with minimal experience are more willing to take risks. This is because more experienced farmers have gained a lot of information about alternative livelihoods such as fishing, boat carrying and trade. So, if there is a crop failure caused by extreme weather, experienced farmers prefer to run alternative livelihoods. Whereas farmers with minimal experience tend to be more challenged to develop seaweed farming activities in order to improve their living standards due to the limited expertise of farmers in seaweed farming, so even though they have experienced serious crop failures, farmers will not stop the routine activities of seaweed cultivation.

\section{Conclusion}

Based on the results of the study, it was concluded that simultaneously ( $F$ test) the area of construction, labor, number of seedlings, number of stretches and farming experience had a significant effect on the productivity of seaweed 
farming. While partially ( $\mathrm{T}$ test) shows that the extent of construction and stretches rope significantly influence productivity. However, the workforce, number of seeds and experience in farming do not affect the productivity of seaweed farming in South Konawe Regency.

\section{References}

i. Anggadiredja, J.T., Purwoto., Zatnika., Istini, S. 2006. Rumput Laut: Pembudidayaan, Pengolahan, Pemasaran Komoditas Perikanan Potensial. Penebar swadaya.Jakarta.

ii. Badan Pusat Statistik. 2015. Sulawesi Tenggara dalam Angka. Kendari.

iii. Buschmann, HA., Camus, c., Infante, j., Neori, A., Israel, A., González, MCH., Pereda, SV., Pinchetti, JLG., Golberg, A., Shalev, NT., \& Critchley, AT. 2017. Seaweed Production: Overview of the Global State of Exploitation, Farming and Emerging Research Activity. European Journal of Phycology Vol 52(4):391-406

iv. Departemen Kelautan dan Perikanan. 2008. Statistik Perikanan Indonesia 2008. Departemen Kelautan dan Perikanan RI. Jakarta.

v. Fausayana, I. 2017. Habitus, Modal dan Kelembagaan Pembudidaya Rumput Laut (dalam Meningkatkan Ekonomi Masyarakat Pesisir). Penerbit Deepublish. Yogyakarta.

vi. Fausayana I., Abdullah W. G., Susanti F., Sidu D., Arimbawa P., Yunus L., 2017 Factors affecting the behavior of farmers toward the risk of seaweed farming in the Bungin Permai village, southeast Sulawesi, Indonesia. AACL Bioflux 10(6):1647-1653.

vii. Fausayana, I, Muhidin., Sidu, D., Arimbawa, P. 2018. Cultivation of Seaweed Eucheuma cottonii on Longline with Floating Inverted Mosquito Net Model. AACL Bioflux, Vol 11 (4): 1009-1014.

viii. Hasibuan, A.M. dan Bedy S. 2008. Daya Saing Usahatani Lada di Lampung. Buletin RISTRI Vol. 1 No.1, 2008.

ix. Kementerian Kelautan dan Perikanan. 2015. Potensi dan Volume Produksi Rumput Laut Indonesia 2014. KKP. Jakarta.

x. Luhur, E,S., Witomo, C.M., Firdaus, M. 2012. Competitiveness of Seaweed Commodity in Indonesia (Case Study: South Konawe Regent South-East Sulawesi). J. Sosek KP Vol. 7 (1):55-67

xi. Ondrej, M. dan Jiri, H. 2012. Total Factor Productivity Approach in Competitive and Regulated World. Procedia Social and Behavioral Sciences. 57 (1): 223-230.

xii. Prihanigrum A., M. Meiyana dan Evalawati. 2001.Biologi Rmput laut; Teknologi Budidaya Rumput Laut (Kappaphycus alvarezii). Petunjuk Teknis. Departemen Kelautan dan Perikanan. Direktorat Jenderal Perikanan Budidaya. Balai Budidaya Laut. Lampung.

xiii. Teniwut, TA, Teniwut R, MK. 2018. Minimizing the instability of seaweed cultivation productivity on rural coastal area: a case study from Indonesia. AACL Bioflux, Vol 11(1): 259-271.

xiv. Umar, H. 2004. Metode Penelitian untuk skripsi dan tesis. Raja Grafindo Persada. Jakarta.

xv. Yusuf, S., Arsyad, M., Nuddin, A. 2018. Prospect of Seaweed Developement In South Sulawesi Through A Mapping Study Approach. IC-FSSAT IOP PublishingIOP Conf. Series: Earth and Environmental Science 157 (2018) 012041. 